\title{
Gender in Irish between continuity and change ${ }^{1}$
}

\author{
Alessio S. Frenda \\ Centre for Language and Communication Studies \\ Trinity College Dublin \\ College Green, Dublin 2 \\ Email: frendaa@tcd.ie
}

\begin{abstract}
The gender system of Irish appears to have undergone a process of simplification: traditionally depending on both formal and semantic assignment rules, agreement in contemporary spoken Irish is still rather conservative within the noun phrase, but almost exclusively semantic anaphorically. Language contact and the resulting obsolescence seem to have had some influence on these developments: for instance, structures that have a functional counterpart in English seem more resilient than others. But language-internal developments, particularly the phonetic erosion and loss of word-final syllables, may have played an important role, too: similar developments have been observed in non-obsolescent languages like Dutch and French. In this paper, I illustrate some specific aspects of the Irish situation with examples drawn from a corpus of spoken Irish and frame the simplification process in terms of structural convergence in the context of language contact.
\end{abstract}

Keywords: Irish, grammatical gender, language change, language obsolescence, contact, convergence

This research was funded by a Government of Ireland Exchange Scholarship and by an IRCHSS Postgraduate Scholarship. I am grateful to the following people for their comments on earlier drafts of this article: John Saeed, Brian Nolan, Gearóid Ó Donnchadha, Pauline Welby and two anonymous reviewers; thanks are also due to Eamonn Mullins for his assistance with the statistical analysis of the data. I take full responsibility for any errors or oversights.

Abbreviations: 1, 2, 3 (first, second, third person); ART (article); cC (contemporary corpus); EMPH (emphatic); GEN (genitive); м (masculine); NEG (negative); NOM (nominative); oc (older corpus); PFX (prefix); PL (plural); pOss (possessive); PRs (present); PST (past); PTC (particle); sG (singular); vN (verbal noun). 


\section{Introduction}

In this paper I present the findings of a comparison between two corpora of spoken Irish, representative, respectively, of a traditional Gaeltacht ${ }^{2}$ variety (as recorded in 1964), and of the contemporary variety heard nowadays on Irish-language media. This investigation focuses on a particular grammatical feature, gender, and on the patterns of agreement variation found in the data.

A brief account of the linguistic situation of Irish today is presented in §2, followed by a description of its grammatical gender system in §3. In §4 I explain how the data were collected and analyzed; the findings are presented and discussed in $\S 5$. In $\S 6$, I present some observations that are relevant to the observed changes; $\S 7$ concludes the article with a few final considerations.

\section{Irish today}

Three major native dialects of Irish survive today, roughly corresponding to their geographical distribution: north (Ulster), west (Connacht) and south (Munster). A standard variety, the Caighdeán ('Standard'; cf. Caighdeán 1979), was created "in order to promote the greater use of Irish not merely in teaching, but also in law, administration, and publications” (Ó Baoill 1988: 112, 114). It took the Translation Section of the Houses of Parliament about forty years to complete the task of standardizing the language; the official standard guide (Gramadach na Gaeilge agus litriú na Gaeilge 'The grammar and spelling of Irish') was published in 1958 and describes an artificial variety which assembles forms and structures taken from the different dialects in an attempt to create a variety that would be accepted by all. The Standard was soon adopted in all educational books and publications written in Irish (Ó Baoill 1988: 114), but was to remain essentially a written variety: attempts were made (starting in the 1960s) to produce a standardized pronunciation, which at any rate was never widely adopted (ibid., p. 123). This artificial standard was generally greeted with hostility by native speakers and purists (Breatnach 1964; Dorian 1994). Nevertheless, as the language of the written media and - to some extent - of the education system, it has been used to approach and win new speakers to the language, amid criticisms that this happened at the expenses of the native Gaeltacht varieties (Breatnach 1964: 20f.; Ó Flatharta 1989: 76). The latter have since been promoted and given more visibility, including through the creation of an Irish-language radio station (Raidió na Gaeltachta 'Radio of the Gaeltacht') in 1972 and a TV channel (TG4, originally Teilifís na Gaeilge 'Irish-language TV') in 1996 (Akutagawa 1987: 138).

Jones's (1998: 5-6) defines obsolescence as "a gradual reduction in use, due to domain restriction, [which] may result in the emergence of historically inappropriate morphological and/or phonological forms together with extensive lexical borrowing”. According to this definition, Irish is today an obsolescent language. Its speakers are all bilinguals (Ó Murchú 1988: 248) and represent a minority of the population: the available figures from the 2006 Census tell us that $40.8 \%$ of the population aged three years and over identified themselves as Irish speakers; however, only about $44 \%$ of the latter (or $18 \%$ of the total) self-reported to ever use Irish outside the education system and only 3\% of them (or 1\% of the total) said they did so daily (CSO 2006: Tables 1 and 40; also see Punch 2008).

"Historically inappropriate forms" resulting from obsolescence can be noticed in various areas of the grammar. In the syntactic domain, for instance, Ó Curnáin (2007a: 36) notes the change in word order from the traditional object pronoun + connective particle + verbal noun, as in example (1), to

${ }^{2}$ Gaeltacht is the Irish term to refer to an officially designated district where Irish is spoken as a community language. 
verbal noun + object pronoun, as in (2). His observation pertains to the Irish of Iorras Aithneach, in the Galway Gaeltacht.

(1) Bhfuil tú i ndan é a shroicheadh?

be.PRs 2sG able 3sG.m PTC reach.vN

'Can you reach it?' (Ó Curnáin 2007a: 36)

(2) Níl mé i ndan reach-áil é.

NEg.be.PRs 1sg able reach-vN 3sg.m

'I can't reach it.' (Ibid.)

As regards phonology, the loss of certain distinctions has been recorded. For instance, a [ \pm TENSE] opposition used to distinguish the sonorants /N, R, L/ from their lenited counterparts /n, l, r/. (This distinction is not represented orthographically.) Today, this opposition is virtually lost (cf. de Bhaldraithe 1953: 257 fnn. 1-3; Ó hUiginn 1994: 560, 562; Ua Súilleabháin 1994: 488; Hickey 2003: 264; Ó Curnáin 2007a: 188-201). Outside the traditional Gaeltacht, Maguire (1991: 199f., $200,203,212$ ) describes the reduction of the phonological inventory with the loss of the traditional opposition of consonantal palatality in a self-established neo-Gaeltacht in Belfast, ${ }^{3}$ and observes that this change affects “even native speakers in strong Gaeltacht areas” (ibid., p. 200) .

From a morphological point of view, Níc Pháidín (2003: 125) records that in the variety of Irish spoken by Gaelscoil pupils ${ }^{4}$ analytical preposition + pronoun forms are used by some speakers instead of the traditional inflected prepositions, as shown in example (3). ${ }^{5}$

(3) Bhí dhá d'iad ann.

be.PST two of 3pL there

'Two of them were there.' (Nic Pháidín 2003: 125; the synthetic form for [of.3PL] is díobh.)

When it comes to grammatical gender, a tendency to simplify the traditional system seems to be common in both branches of the Celtic family. These are Q-Celtic (which includes Irish and Scottish Gaelic, Manx) and P-Celtic (which includes Welsh, Cornish and Breton). In the final stages of Manx and Cornish, now both extinct, ${ }^{6}$ the gender of inanimates ceased to be distinguished and marked (see $\S 6$ below). The uncertain gender assignment of inanimates has been observed not only in the varieties of younger speakers (e.g. in Welsh, cf. Jones 1998) or in non-traditional varieties (e.g. in the Belfast neo-Gaeltacht, cf. Maguire 1991: 211); but also in the varieties of some older speakers, which also show similar developments or incipient stages thereof, particularly as regards the overgeneralization of masculine pronouns for inanimate antecedents of feminine gender in anaphoric reference: see Jones (1998: 66, 171) for Welsh, Ó Siadhail (1984: 177; 1989: 148f.) for Donegal Irish, Dorian (1976 and 1981: 124-129) for East Sutherland Gaelic (a variety of Scottish

3 This neo- (i.e. non traditional) Gaeltacht, also known as the Shaw's Road Gaeltacht, was unofficially established in 1969 by little less than forty Irish-speaking families; some of them had connections with the traditional Donegal Gaeltacht, but most of them were couples who had learned Irish as adults and wanted a supportive environment to raise their own children as Irish speakers (Maguire 1991: 67f.).

4 Gaelscoil is the Irish name for an Irish-language primary or secondary school where children are taught through the medium of Irish.

5 The use of analytic expressions with emphatic pronouns, e.g. air i-se (on 3sG.F-EMPH) instead of uirthi-se (on.3sG.FEMPH) is also noted by Ó Curnáin (2007b: 1278-1280) in the Irish of Iorras Aithneach, a Gaeltacht variety.

6 An anonymous reviewer criticizes the use of the adjective extinct as not entirely appropriate in the case of Manx, since there is a "lively Manx speaking community complete with a Manx-medium school". When this community of revivalists was established, the few extant native speakers of Manx were still alive and the revivalists learned the language from them (see George \& Broderick 1993: 654-660). Here, the term “extinct” in reference to Manx should be understood as shorthand for "no longer spoken natively". 
Gaelic).

\section{Gender in Irish}

Except insofar as regional variation may exist in the assignment of particular nouns, the traditional gender system of Irish is still common to the three dialects. ${ }^{7}$

Gender assignment in Irish can be described in terms of both semantic and formal rules. Corbett (1991) distinguishes two types of formal rules: (i) phonological rules, if one form of the noun is sufficient to predict its gender, and (ii) morphological rules, if the knowledge of two or more forms is necessary. With very few exceptions, the gender of animates in Irish is semantically determined by the sex of their referents, where this is an explicit semantic feature of the noun: nouns for males are masculine and nouns for females feminine. Notable exceptions include cailín 'girl', which denotes a female human but is masculine, and stail 'stallion', which denotes a male animate but is feminine.

Gender agreement is marked on a number of targets, both within the noun phrase and pronominally; traditionally, agreement tends to be consistently marked across the various targets, except when there is a clash between semantic and grammatical gender. In that case, NP-internal targets agree syntactically while pronouns agree semantically. ${ }^{8}$

Grammarians have long noted the correlation between grammatical gender and inflectional classes (see Mac Eoin 1993: 114-115). ${ }^{9}$ However, following the decline of traditional case marking, to which I will return later, formal gender assignment has undergone a certain amount of simplification; a tendency to take the quality of the final consonant of the nominative singular as an indicator of its gender has emerged in some varieties. A palatal final consonant is thus considered a feminine ending and a non-palatal one a masculine ending (phonological assignment). This can be considered the analogical extension of a rather strong correlation found in the traditional system. As a result, a number of historically feminine nouns ending in a non-palatal consonant in the nominative have been reassigned to the masculine gender; in a number of other instances, their ancient nominative has been replaced by an erstwhile dative form, where this happened to end in a palatal consonant, so as to maintain the correlation. Conversely, masculine nouns formed with the agentive suffix -éir (with final palatal $/ \mathrm{r}^{\prime} /$ ) may adopt the erstwhile genitive form -éara (without palatal ending) as their new nominative form (Ó Siadhail 1984: 174, 1989: 145; Ua Súilleabháin 1994: 492).

Targets of gender agreement are in Irish the article, the attributive adjective and third-person singular pronouns. ${ }^{10}$ Agreement can be marked word-finally or word-initially; in the latter case this is done by means of the following types of initial mutations:

1. lenition, orthographically indicated by the letter $h$ after the sign of the mutated consonant (e.g. $p>p h / f /$ ). The effect of lenition is generally to turn a stop into its homorganic

\footnotetext{
As mentioned above, the overgeneralization of masculine pronouns for inanimate referents in Donegal (Ulster Irish) has been observed for some time, but Ulster Irish was not included in this study.

8 This is always the case for human referents, but not for all animates; e.g. in the case of aforementioned stail 'stallion' the use of feminine pronouns is attested in the traditional varieties (Ó Siadhail 1984).

$9 \quad$ Also cf. Thurneysen (1980: $\S \S 252,276-341)$ and McManus (1994: 368-382) for a historical overview of the correlation between gender and declensions in Old Irish and Classical Modern Irish, respectively.

10 Attributive nouns, i.e. nouns which immediately follow the controller within the same noun phrase, are sometimes treated as adjectives in terms of initial lenition. However, there is inter-dialectal variation in the extent to which this is the case, as well as several exceptions (cf. de Bhaldraithe 1953: 262 for Connemara Irish and Ó Sé 2000: 61f. for Munster Irish; also see Caighdeán 1979: 83-84 for the Standard).
} 
fricative, but the system is not perfectly symmetrical and it also applies to a few consonants that are already fricative. For a comprehensive overview, see Ó Siadhail (1989: 112); ${ }^{11}$

2. /t/-prefixing;

3. /h/-prefixing.

Gender agreement between the noun and the article is marked both morphologically (on the article itself) and via initial mutation (on the noun). It is common to represent this state of affairs by writing a superscript letter after the article; e.g. $a n^{L}$ indicates that the noun is lenited after the article, while $a n^{T}$ and $n a^{H}$ that /t/ or /h/, respectively, is prefixed to the noun.

In the genitive singular, article-noun agreement is marked in both ways: cf. $a n^{L}$ vs. $n a^{H}$ in example (4).

(4) $\mathrm{a}$

$$
\begin{aligned}
& \text { cóta an } n^{L} \text { pháiste } \\
& \text { coat(M).NOM.SG ART.GEN.M.SG child(M).GEN.SG } \\
& \text { 'the child's coat' (cf. unmutated páiste 'child') } \\
& \text { b. barr } n a^{H} \quad \text { h-aille } \\
& \text { top(M).NOM.SG ART.GEN.F.SG PFX-cliff(F).GEN.SG } \\
& \text { 'the top of the cliff' }
\end{aligned}
$$

In the nominative singular, on the other hand, agreement is only marked by the appropriate initial mutation: cf. $a n^{T}$ vs. $a n^{L}$ in example (5).

(5)
$a n^{T} \quad \underline{t}$-athair
ART.NOM.M.SG PFX-father(M).NOM.SG
'the father'
b. $a n^{L} \quad$ bhean
ART.NOM.F.SG WOman(F).NOM.SG
'the woman'

The attributive adjective may also mark gender agreement in both ways, although morphological agreement with this target is not very frequent and is almost only preserved in set phrases (Mac Eoin 1993: 115-116). Example (6) is drawn from my database (see §4.1 below).

(6) Cuan an $\quad$ Fhir $\quad \underline{\text { Mhóir }}$

harbour(M).NOM.SG ART.GEN.M.SG man(M).GEN.SG big.GEN.M.SG

(place name: cf. the nominative singular form an fear mór 'the big man')

Third-person singular pronouns mark gender agreement morphologically or via initial mutation according to their morphosyntactic type: simple direct pronouns mark agreement morphologically (e.g. m. sé [3sG.m] 'he/it' vs. f. sí [3sG.F] 'she/it'), as do prepositional pronouns (e.g. m. dó [do + 3sG.m] 'to him/it' vs. f. $d i$ [do + 3sG.F] 'to her/it'); possessive pronouns only mark agreement via initial mutation, as in example (7).

\footnotetext{
11 As observed above, the sonorants /N, R, L/ were also traditionally lenited, i.e. made [-TENSE], but since this opposition is now lost even among native speakers, it was not taken into account.
} 
$\begin{array}{llll}\text { (7) a. } & \text { fear }_{i} \ldots & a^{L} & \text { chóta } \\ & \text { man(M).NOM.SG } & \text { POSs.3sG.M } & \text { coat(M).NOM.SG }\end{array}$

'a man ... his coat'

b. bean $_{j} \ldots \quad a_{j} \quad$ cóta

woman(F).NOM.SG POSS.3sG.F coat(M).NOM.SG

'a woman ... her coat'

\section{Methodology}

\subsection{The data}

I analyzed two corpora of spoken Irish, which will be referred to as the older and the contemporary corpus, respectively. The comparison between these two is meant to show that the inconsistent agreement patterns observed in the contemporary corpus do not reflect those of traditional native varieties of Irish.

\subsubsection{The older corpus}

The older corpus is a collection of recordings made in 1964 in the village of Ros Muc, in the Connemara Gaeltacht (County Galway). As such, it represents a variety of the Connacht dialect. The recordings were made during a series of informal conversation sessions between a younger member of the local community - the facilitator - and one or two older community members, who were invited to recount personal experiences. All the contributors were born between 1896 and 1937: five of them were born between 1896 and 1914 and were either fishermen or farmers, while the youngest two were born in 1937, one of them an electrician and the other a teacher. The latter was the facilitator and his contribution to the corpus is minimal, consisting in just a few interspersed questions meant to either start the session or invite another speaker to intervene. The resulting material was edited and published in 2000 by Arndt Wigger (Wigger 2000) and is also available online - original recordings included - from the website of the Dublin Institute for Advanced Studies. ${ }^{12}$ Because certain speakers in Wigger's corpus are much more represented than others, only a portion of the corpus was used, so that no single speaker would be over-represented. The selection I used totals about 12,200 words.

\subsubsection{The contemporary corpus}

The contemporary corpus comprises approximately 20,000 words and includes transcriptions of spontaneous conversations from Irish-language radio shows. This corpus is meant to represent the type of input available to contemporary Irish speakers through the broadcasting medium and is subdivided into two components. The first component includes seven texts (approximately 13,000 words) from the national Gaeltacht-based broadcaster, Raidió na Gaeltachta (henceforth "RnaG”); the second component includes four texts (approximately 7,000 words) from other non-Gaeltacht sources, including two Dublin-based radio stations (Raidió na Life and Newstalk) and a podcast series. ${ }^{13}$ The shows were broadcast between 1997 and 2007 and were transcribed by the author with the assistance of three Irish speakers. The contemporary corpus features 25 speakers, who can be divided into six groups based on their estimated year of birth:

(a) 1925-1935: one speaker (all from RnaG);

http://tiny.cc/e7uc8 (last accessed on 24 February 2011).

13 An interview from an episode of the podcast series “An Líonra Sóisialta”, http://tiny.cc/7ijn7 (last accessed on 24 February 2011). 
(b) 1936-1945: two speakers (all from RnaG);

(c) 1946-1955: six speakers (all from RnaG);

(d) 1956-1965: seven speakers (six from RnaG);

(e) 1966-1975: eight speakers (three from RnaG);

(f) 1976-1985: one speaker (from Newstalk).

The contemporary corpus is meant to represent the two main varieties of Irish spoken today: native (or near-native) and non-native. It should be noted that it is not always uncontroversial, in the Irish context, who should be considered a native speaker (cf. Ó Giollagáin \& Mac Donnacha 2008:

111f.); for instance, someone who was raised through Irish from birth by L2 Irish-speaking parents, and then attended an Irish-language school, may regard him/herself as a native speaker of Irish even though his/her parents weren't; so may someone who was raised in the Gaeltacht by Irish-speaking parents but mainly through English, and subsequently re-adopted Irish as the language of their social and/or professional life. Because such distinctions are sometimes difficult to make and a speaker's own assessment may be biased by his or her allegiance to the language, an informed judgement has to depend on a detailed linguistic biography of the speaker in question, something which is not readily available in the case of a corpus of radio broadcasts. For this reason, I decided I would consider RnaG speakers as representative of, or at least closer to, traditional native varieties, and speakers on other radio stations as representative of non-native varieties.

The choice of Wigger's corpus as the older corpus was dictated by the fact that both the audio recordings and a set of transcriptions were available. A corpus of radio-broadcast shows from the early Seventies, when Irish-language broadcasting was first established, is not available yet.

\subsubsection{Procedure}

According to Corbett (1991), it is the agreement forms taken by any given noun that tell us in what gender or class it belongs. Defining deviant gender assignment might therefore prove problematic: if a certain speaker consistently produces masculine agreement forms with a historically feminine noun, we must conclude that in his or her grammar that noun is masculine and that therefore masculine forms are to be expected..$^{14}$ Moreover, should gender assignment be found to diverge significantly from speaker to speaker, analyzing the consistency of agreement across target types would be more complicated since it would be necessary to take into account not just each lexical item but also which speaker uttered them. Furthermore, if a speaker uses a historically unexpected agreement form with a noun he or she only utters once, it would be impossible to establish whether they have reassigned the noun or just made an occasional performance mistake.

However, as we shall see, gender assignment was found to be remarkably consistent and in line with historical expectations - in both corpora - for at least one agreement target, the article; this was not the case for other agreement targets and it was thus possible to assess agreement consistency by contrast.

Each text was scanned manually in order to retrieve all the instances in which gender agreement could be marked. The agreement rate for each target type was then calculated as the ratio between

14 An anonymous reviewer comments that since masculine agreement is not marked by lenition, there is no evidence that the speaker treats the noun in question as masculine; he or she might just be ignoring gender; he adds that only if masculine agreement is consistently found anaphorically can we argue that the speaker treats the noun as masculine. To this I would respond that, on the one hand, masculine agreement is in fact marked by lenition in the genitive and is also marked by what is traditionally analyzed as a prefixed $t$ - in the nominative, if the noun is vowelinitial: therefore, masculine agreement in the noun phrase may be positively recognized as such and not just as the unmarked form. On the other hand, if a speaker produces feminine agreement forms with other traditionally feminine nouns, then we must conclude that his or her grammar still retains a distinction between the two genders. 
the number of instances in which syntactic agreement was observed and the total number of instances in which agreement could be marked. Because counts were somewhat small for particular data subsets and target types, it was decided to use Fisher's exact test to test the statistical significance of the difference between proportions. ${ }^{15}$ Statistical significance was assumed for pvalues smaller than 0.05 .

\section{Findings}

\subsection{Agreement with the article}

In the older corpus, the expected form of the article and/or the expected mutation of the following noun were observed $98 \%$ of the time with masculine nouns and $97 \%$ of the time with feminine nouns, as shown in Table 1 . The difference in agreement rate was not significant. In the contemporary corpus (Table 2), on the other hand, the difference in agreement rate between the two genders appears to be statistically significant, with feminine nouns agreeing $88 \%$ of the time as opposed to masculine nouns, which show an agreement rate of $97 \%$.

\begin{tabular}{lcc}
\hline & Masc. & Fem. \\
\hline Agreeing & 227 & 107 \\
Total & 232 & 110 \\
$\%$ & 98 & 97 \\
\hline \multicolumn{2}{c}{$\mathrm{p}=0.7154$}
\end{tabular}

Table 1. Agreement with the article in the older corpus.

\begin{tabular}{lcc}
\hline & Masc. & Fem. \\
\hline Agreeing & 176 & 136 \\
Total & 182 & 155 \\
$\%$ & 97 & 88 \\
\hline \multicolumn{2}{c}{$\mathrm{p}=0.0028$} \\
\hline
\end{tabular}

Table 2. Agreement with the article in the contemporary corpus.

The difference in agreement rate with the article is statistically significant in both components of the contemporary corpus: lower agreement rates with feminine nouns than with masculine ones are observed in both components (Table 3). This suggests uniformity between them in this respect and allows the comparison between the contemporary corpus as a whole and the older corpus.

\begin{tabular}{lcclcc}
\hline & \multicolumn{2}{c}{ RnaG } & & \multicolumn{2}{c}{ Others } \\
\cline { 2 - 3 } \cline { 5 - 6 } & Masc. & Fem. & & Masc. & Fem. \\
\hline Agreein & 114 & 103 & & 62 & 33 \\
g & 118 & 115 & & 64 & 40 \\
Total & 97 & 90 & & 97 & 82.5 \\
$\%$ & & & & \\
\hline & $\mathrm{p}=0.0395$ & & $\mathrm{p}=0.0256$ \\
\hline
\end{tabular}

Table 3. Agreement with the article in the contemporary corpus, RnaG vs. others.

Overall, as can be seen in Table 4, feminine agreement forms with the article are statistically

15 I used the software R (http://cran.r-project.org/). 
significantly more frequent in the older corpus (97\%) than in the contemporary one (88\%). It would have been interesting to ascertain if agreement rates are higher in the case of semantic gender agreement, i.e. with nouns that have male or female referents. However, this could not be done, since only two occurrences of explicitly semantic agreement were found (one in the older corpus and one in the contemporary one).

\begin{tabular}{lccccc}
\hline & \multicolumn{2}{c}{ Overall } & & \multicolumn{2}{c}{ Excl. proper names } \\
\cline { 2 - 3 } & Fem. (OC) & Fem. (CC) & & Fem. (OC) & Fem. (CC) \\
\hline Agreeing & 107 & 136 & & 107 & 123 \\
Total & 110 & 155 & & 110 & 142 \\
$\%$ & 97 & 88 & & 97 & 87 \\
\hline \multicolumn{2}{c}{$\mathrm{p}=0.0059$} & & \multicolumn{2}{c}{$\mathrm{p}=0.0029$} \\
\hline
\end{tabular}

Table 4. Article agreement with feminine controllers, older vs. contemporary corpus.

Beside semantic agreement, another factor which may be thought to affect agreement rate: if a proper or place name is a noun phrase that contains an agreement form, as in example (8), it might be misleading to regard it as a case of productive agreement, under the hypothesis that such noun phrases are stored in the lexicon as unanalyzed units.

(8) $A n^{L} \quad$ Ghráig

ART.NOM.F.SG village(F).NOM.SG

(a placename)

Therefore, proper and place names (13 feminine observations in the contemporary corpus, none found in the older one) were removed from the samples in order to carry out the above comparison a second time. As shown in the two rightmost columns of Table 4, this factor was found to have a negligible impact on agreement rates, which were almost unaltered, while the between-corpus difference remained statistically significant.

To summarize, the gender of the controller does not affect agreement rates with the article in the older corpus, but it does so in the contemporary corpus, where agreement with masculine nouns is more regular than with feminine ones. Diachronically, agreement rate with feminine controllers appears to be significantly more frequent in the older corpus than in the contemporary one.

\subsection{Agreement with the adjective}

As we have seen, attributive adjectives can mark gender agreement both via initial mutation and morphologically. Morphological agreement may only be found in the genitive singular, just 11 tokens of which were recorded (six in the older corpus and five in the contemporary one) ${ }^{16}$ No meaningful generalization could therefore be made about the productivity of morphological agreement, and what follows only refers to agreement marking by means of initial mutation.

As show in Table 5, masculine agreement is in no significant way more frequent than feminine agreement in the older corpus. In the contemporary corpus, on the other hand, masculine agreement is about twice as likely as feminine agreement (Table 6). A statistically significant difference in agreement rate with controllers of different gender is also recorded in each of the two components of this corpus (RnaG vs. others): as can be seen from Table 7, adjective agreement with masculines is more frequent than with feminines in both. Diachronically, adjective agreement with feminine

16 Morphological gender marking was only possible in six of these, where it was found as expected. 
controllers is about twice as likely in the older corpus than in the contemporary one ( $92 \%$ vs. $45 \%$, respectively), as shown in Table 8.

\begin{tabular}{lcc}
\hline & Masc. & Fem. \\
\hline Agreeing & 49 & 33 \\
Total & 52 & 36 \\
$\%$ & 94 & 92 \\
& \multicolumn{2}{c}{$\mathrm{p}=0.6853$}
\end{tabular}

Table 5. Agreement with the adjective in the older corpus.

\begin{tabular}{lcc}
\hline & Masc. & Fem. \\
\hline Agreeing & 51 & 9 \\
Total & 56 & 20 \\
$\%$ & 91 & 45 \\
\hline \multicolumn{2}{c}{$\mathrm{p}<0.0001$} \\
\hline
\end{tabular}

Table 6. Agreement with the adjective in the contemporary corpus.

\begin{tabular}{lccccc}
\hline & \multicolumn{2}{c}{ RnaG } & & \multicolumn{2}{c}{ Others } \\
\cline { 2 - 3 } \cline { 5 - 6 } & Masc. & Fem. & & Masc. & Fem. \\
\hline Agreeing & 33 & 8 & & 18 & 1 \\
Total & 35 & 14 & & 21 & 6 \\
$\%$ & 94 & 57 & & 86 & 17 \\
\hline & $\mathrm{p}=0.0042$ & & \multicolumn{2}{c}{$\mathrm{p}=0.0037$} \\
\hline
\end{tabular}

Table 7. Agreement with the adjective, RnaG vs. others.

\begin{tabular}{lcc}
\hline & Fem. (OC) & Fem. (CC) \\
\hline Agreeing & 33 & 9 \\
Total & 36 & 20 \\
$\%$ & 92 & 45 \\
\hline \multicolumn{2}{c}{$\mathrm{p}=0.0002$} \\
\hline
\end{tabular}

Table 8. Adjective agreement with feminine controllers.

As was the case with the article, the impact of semantically motivated assignment on agreement rates could not be assessed, since only two occurrences of semantic agreement were found (both in the older corpus). There were, on the other hand, a few more examples of proper and place names. In the older corpus seven such occurrences were counted, like the place name in example (9), all of which showed the expected agreement forms.

\section{(9) Aill Bhuí \\ cliff(F).NOM.sG yellow.NOM.F.sG 'Yellow Cliff'}

However, as with the article, to exclude these tokens from the sample does not significantly alter the picture, as shown in Table 9: the between-gender difference in agreement rate remains statistically not significant in the older corpus $(\mathrm{p}=0.67)$ and statistically significant in the contemporary one ( $\mathrm{p}<0.0001)$. The between-corpus difference in agreement rate with feminine nouns also remains statistically significant ( $90 \%$ in the older corpus vs. $42 \%$ in the contemporary one), as shown in Table 10. 


\begin{tabular}{lccccc}
\hline & \multicolumn{2}{c}{ Older corpus } & & \multicolumn{2}{c}{ Contemporary corpus } \\
\cline { 2 - 3 } \cline { 5 - 6 } & Masc. & Fem. & & Masc. & Fem. \\
\hline Agreeing & 47 & 28 & & 49 & 8 \\
Total & 50 & 31 & & 54 & 19 \\
$\%$ & 94 & 90 & & 91 & 42 \\
\hline \multicolumn{2}{c}{$\mathrm{p}=0.67$} & & \multicolumn{2}{c}{$\mathrm{p}<0.0001$} \\
\hline
\end{tabular}

Table 9. Agreement with the adjective, excluding proper names.

\begin{tabular}{lcc}
\hline & Fem. (OC) & Fem. (CC) \\
\hline Agreeing & 28 & 8 \\
Total & 31 & 19 \\
$\%$ & 90 & 42 \\
\hline \multicolumn{2}{c}{$\mathrm{p}=0.0007$}
\end{tabular}

Table 10. Adjective agreement with feminine controllers, older vs. contemporary corpus, excluding proper names.

In passing, it can be observed that attributive adjectives are somewhat infrequent in the data, with less than 100 occurrences in either corpus (but bearing in mind that only adjectives that had the morphological or phonological means to mark gender agreement were counted). This state of affairs is consistent with Mac Eoin's (1993: 116) remark about the decline of the attributive position in spoken Irish, perceived as "bookish” and generally avoided.

To recap, the data show that gender agreement patterns for attributive adjectives are similar to those we have already observed for the article. The gender of the noun does not affect agreement rates in the older corpus but does so in the contemporary corpus, where agreement with feminine nouns is less frequent than with masculine ones. Diachronically, agreement with feminine nouns in the contemporary corpus was found to be significantly less likely than in the older one.

\subsection{Pronominal agreement}

Pronouns were divided into the following three groups for analytical purposes:

1. simple pronouns (e.g. sé [3sg.m] 'he/it');

2. prepositional pronouns (e.g. aige [at.3sG.m] 'at him/it');

3. possessive pronouns (e.g. $a^{L}$ [POss.3sG.m] 'his/its').

This was motivated both by the different formal properties of the three groups and on theoretical grounds. Formally, there is a difference between the agreement-marking devices available to types 1 and 2 (morphological) and those available to type 3 (initial mutation); from a theoretic point of view, it has been observed in the literature (Ó Curnáin 2007b: 1261) that the overgeneralization of masculine anaphors with feminine inanimate antecedents is more frequent for prepositional than for simple pronouns.

A further distinction is made in the literature between anaphora and cataphora. Ó Curnáin (2007b: 1260-1261) reports that in Iorras Aithneach the cataphoric position also favours the 
overgeneralization of masculine pronouns with feminine inanimate antecedents. Cataphoric pronouns with feminine antecedents are extremely rare in our data (two were found in the contemporary corpus and one in the older corpus), so no generalization can be made; however, consistently with Ó Curnáin’s observation, they are all masculine forms.

I discarded all instances of complex anaphora (in the sense of Consten et al. 2007), i.e. expressions with a propositionally structured antecedent and a conceptually complex referent. Because in complex anaphora the antecedent is not a noun, there is no question of the grammatical gender of the anaphoric pronoun agreeing or not agreeing syntactically. By default, complex anaphora is realized by means of masculine pronouns, but feminine pronouns may also be found if there is a feminine predicate, as in the following example.

(10) T: $\quad$ Bhoil anois, is faoi is mó a bhí muid ag caint an oíche cheana faoin mbádóireacht, ar ndóigh, 'sí is gaire do do chroí.

M: $\quad$ 'Sí ar ndóigh an chéad turn...

T: $\quad$ Agus, t'athair, agus is dóigh d'athair mór romhat.

M: $\quad$ Muise 'sin í an fhírinne.

'Well now, this is what we were talking about the most the other night, boating, of course, you're very fond of it. - I am, of course. - And so was your father, and of course your grandfather before you. - Indeed, that's the truth.'

In example (10), $\sin$ ('that') is a complex anaphor, whose antecedent is a statement of which $\mathrm{M}$ is predicating the truth value (that boating has been a central activity in his family for generations). The feminine pronominal form í is semantically redundant, but syntactically required when the predicate is expressed by a definite noun phrase (here, an fhírinne 'the truth'), ${ }^{17}$ and is feminine by attraction in the gender of the predicate noun phrase, headed by feminine fírinne. ${ }^{18}$

However, this gender attraction is not always observed. According to de Bhaldraithe (1953: 138), who describes the dialect of Cois Fhairrge in the same Gaeltacht, the appearance of attraction is lexically determined: attraction is traditionally found with certain feminine nouns (e.g. fírinne 'truth', ceist 'question') but not with other equally feminine ones (e.g. caoi 'way', tuairim 'opinion'). It is reasonable to assume that frequency of use and formularity have played an important role in defining the norm for each lexical item. Other studies of Gaeltacht varieties in County Galway have highlighted that masculine pronouns are increasingly common in this type of constructions, regardless of the gender of the predicate noun phrase (cf. Ó Curnáin 2007b: 12601261). Because gender attraction (or the lack thereof) seems to be a lexically determined and largely idiosyncratic phenomenon even in traditional varieties, and because it does not represent agreement with the antecedent, it was not taken into account in this study.

\subsubsection{The older corpus}

The first striking observation in relation to the older corpus is that out of the exactly 100 feminine pronouns contained therein, 57 have grammatically masculine antecedents; by contrast, only $2 \%$ of the masculine pronouns have grammatically feminine antecedents (Table 11). Ten of the 57 feminine pronouns in question are instances of semantic agreement (grammatically masculine

17 On the insertion of this redundant pronoun see Ó Nualláin (1911), Carnie (1995: 164-168) and Doherty (1996: 2736).

18 Had the predicate been expressed by an adjective, e.g. fíor 'true', a different 'be' verb and a different syntactic structure would have been used: tá sé sin fíor 'that's true'. The complex anaphor (subject noun phrase) would have been instantiated by the pronominal constituent sé sin [3sG.m + distal marker], masculine singular. 
antecedents but female referents); another 42 refer to a very specific lexico-semantic category, which includes masculine bád 'boat', soitheach 'vessel' and púcán (a type of fishing boat). According to Ó Siadhail (1984), members of this lexico-semantic category take feminine pronominal reference, even if grammatically masculine, in all dialects. So 52 out of 57 mismatching pronouns could be accounted for as either semantically agreeing or otherwise in line with wellestablished traditional norms and were therefore discarded before assessing the frequency of pronominal agreement in this corpus.

\begin{tabular}{lcc}
\hline & Total & With same-gender antecedent \\
\hline Masc. pronouns & 359 & $98 \%(351)$ \\
Fem. pronouns & 100 & $43 \%(43)$ \\
\hline
\end{tabular}

Table 11. Gender of pronouns and of their antecedents in the older corpus.

In Table 12 and in all subsequent tables the row labelled "Total" contains the total number of pronouns used anaphorically with antecedents of each gender ${ }^{19}$ while the row labelled "Agreeing" specifies the number of pronouns that were found to agree syntactically with their antecedent. As Table 12 shows, syntactic agreement with masculine antecedents in the older corpus is significantly more frequent than with feminine ones: overall, agreement is observed $99 \%$ of the time with masculine antecedents and 84\% with feminine ones and the difference between the two proportions is statistically significant. If we discard all instances of semantic agreement, the picture is virtually unchanged, with an agreement rate of $98 \%$ for masculines and $83 \%$ for feminines, and again a significant difference.

\begin{tabular}{lccccc}
\hline & \multicolumn{2}{c}{ Overall } & & \multicolumn{2}{c}{ Excl. sem. agr. } \\
\cline { 2 - 3 } & Masc. & Fem. & & Masc. & Fem. \\
\hline Agreeing & 351 & 43 & & 124 & 40 \\
Total & 354 & 51 & & 127 & 48 \\
$\%$ & 99 & 84 & & 98 & 83 \\
\hline & \multicolumn{2}{c}{$\mathrm{p}<0.0001$} & & $\mathrm{p}=0.0016$ \\
\hline
\end{tabular}

Table 12. Pronominal agreement in the older corpus.

When these figures are broken down by pronoun type (simple, prepositional and possessive), we observe similar agreement rates (i.e., rates greater than $95 \%$ for the masculine and around $85 \%$ for the feminine), as shown in Table 13: however, we also get smaller counts and the difference appears to be only border-line statistically significant for simple and prepositional pronouns $(\mathrm{p}=0.0407$ and $\mathrm{p}=0.0675$, respectively); as regards possessive pronouns, there are too few observations to allow a meaningful comparison. It was thus impossible to establish whether the agreement-marking device (morphology vs. initial mutation) is in any way correlated to pronominal agreement rates.

\begin{tabular}{|c|c|c|c|c|c|c|}
\hline & \multicolumn{2}{|c|}{ Simple } & \multicolumn{2}{|c|}{ Prep. } & \multicolumn{2}{|c|}{ Poss. } \\
\hline & Masc. & Fem. & Masc. & Fem. & Masc. & Fem. \\
\hline Agreeing & 82 & 20 & 32 & 20 & 10 & 0 \\
\hline Total & 85 & 24 & 32 & 23 & 10 & 1 \\
\hline$\%$ & 96 & 83 & 100 & 87 & 100 & 0 \\
\hline
\end{tabular}

19 Note that the same antecedent may be resumed by one or more pronouns. 


$$
\mathrm{p}=0.0407 \quad \mathrm{p}=0.0675
$$

Table 13. Pronominal agreement in the older corpus by pronoun type, excluding semantic agreement.

\subsubsection{The contemporary corpus}

Whereas in the older corpus a rather high proportion of feminine pronouns with grammatically masculine antecedents was observed, this was not the case in the contemporary corpus. Here, as shown in Table 14, only four feminine pronouns have masculine antecedents. One is a straightforward case of semantic agreement with the masculine epicene cara 'friend', whose referent is a woman, while not much can be said about the other three, involving masculine antecedents such as scairdphaca 'jet-pack', stáisiún 'station' and bus 'bus', for which nothing suggests that the feminine pronouns should be attributed to other than once-off deviations. As regards masculine pronouns with grammatically feminine antecedents, they represent about $7 \%$ of them (17 pronouns). Among these, we find the following:

1. simple and prepositional pronouns co-referential with feminine áit 'place' (both RnaG and others);

2. simple pronouns co-referential with feminine argóint 'argument' (non-RnaG);

3. simple pronouns co-referential with feminine áilleacht 'beauty' and timpeallacht 'environment' (RnaG);

4. simple pronouns co-referential with feminine Gaelainn 'Irish language'(RnaG); ${ }^{20}$

5. possessive pronouns co-referential with feminine cuid 'portion'(non-Rnag) and obair 'work' (RnaG).

\begin{tabular}{lcc}
\hline & Total & With same-gender antecedent \\
\hline Masc. pronouns & 229 & $93 \%(212)$ \\
Fem. pronouns & 23 & $83 \%(19)$ \\
\hline
\end{tabular}

Table 14. Gender of pronouns and of their antecedents in the contemporary corpus.

For some of these a few considerations should be added. To begin with, the occurrence of masculine pronouns that co-refer with feminine áit is not a recent innovation. De Bhaldraithe (1953: 135-136), for instance, lists áit as one of the few feminine nouns regularly taking masculine anaphors in Cois Fhairrge Irish, and the same is observed by Ó Sé (2000: 87) apropos of the Corca Dhuibhne variety. ${ }^{21}$ Nevertheless, one feminine pronoun is quite unexpectedly recorded with áit in the RnaG section of the contemporary corpus. ${ }^{22}$

Áilleacht and timpeallacht may be grouped together on a morphological basis: nouns ending in the derivational suffix -acht (/əxt/) are normally feminine but, as we have seen, non-palatal endings

20 Gaelainn is a Munster Irish word (elsewhere the Irish language is called Gaeilge); an anonymous reviewer commented that the linguistic production of Munster speakers should not be compared with that of Connemara speakers (i.e. the older corpus). However, the traditional gender systems of both Munster and Connemara Irish are comparable as systems: in both dialects, gender agreement reflected grammatical gender. Even though individual nouns may well be of different genders in different dialects, agreement tended to be consistent with that particular gender, both within the noun phrase and with anaphoric pronouns. Even the exceptions to this rule tend to be the same in the various dialects, as in the case of feminine áit (see below) or the names for boats and ships (see above).

21 However, masculine agreement with áit was not observed within the noun phrase.

22 The speaker in question was a native Irish speaker from Corca Dhuibhne (Munster) and one of the oldest in this corpus; he had emigrated to New Zealand in his youth, where he had lived for forty years before moving back to his native area. 
such as these also tend to be associated with the masculine gender. Semantically they are both abstract (like the aforementioned argóint), and abstract nouns are a category with which other studies have found the overgeneralization of masculine pronouns to be particularly likely (cf. Ó Curnáin 2007b: 1259).

As can be seen in Table 15, agreement with masculine controllers is about twice as frequent as agreement with feminine ones (98\% vs. 53\%, respectively), and about four times as frequent if semantic agreement is ignored ( $98 \%$ vs. $26 \%$, respectively). In both cases, the difference is statistically significant. Only six pronouns agree with inanimate antecedents of feminine gender (of these, five come from the RnaG component). The use of feminine pronouns with inanimate referents is clearly quite rare in this corpus, and insofar as these figures can be generalized to contemporary spoken Irish as a whole, they suggest that the use of masculine pronouns with feminine inanimates is becoming increasingly acceptable. The analysis of a larger corpus, at present unavailable, is still necessary to establish whether such a generalization is warranted.

\begin{tabular}{lccccc}
\hline & \multicolumn{2}{c}{ Overall } & & \multicolumn{2}{c}{ Excl. sem. agr. } \\
\cline { 2 - 3 } \cline { 5 - 5 } & Masc. & Fem. & & Masc. & Fem. \\
\hline Agreeing & 212 & 19 & & 145 & 6 \\
Total & 216 & 36 & & 148 & 23 \\
$\%$ & 98 & 53 & & 98 & 26 \\
\hline & $\mathrm{p}<0.0001$ & & $\mathrm{p}<0.0001$ \\
\hline
\end{tabular}

Table 15. Pronominal agreement in the contemporary corpus.

The hypothesized difference in agreement rate with the three different types of pronouns could not be assessed due to the scarcity of relevant data: out of 36 pronouns with feminine antecedents, as many as 29 were simple pronouns; excluding semantic agreement, there were 18 simple pronouns on a total of 23; this leaves only seven non-simple pronouns with feminine antecedents (only five, if semantic agreement is disregarded).

Agreement rates with masculine antecedents, on the other hand, are very high for all three pronoun types, as shown in Table 16: over $98 \%$ for both simple and prepositional pronouns ${ }^{23}$ and $92 \%$ for possessive pronouns ( $80 \%$ when semantic agreement is not counted).

\begin{tabular}{lcccccc}
\hline & \multicolumn{3}{c}{ Overall } & \multicolumn{3}{c}{ Excl. sem. agr. } \\
\cline { 2 - 7 } & Simple & Prep. & Poss. & Simple & Prep. & Poss. \\
\hline Agreeing & 141 & 60 & 11 & 104 & 37 & 4 \\
Total & 143 & 61 & 12 & 106 & 37 & 5 \\
$\%$ & 99 & 98 & 92 & 98 & 100 & 80 \\
\hline
\end{tabular}

Table 16. Pronominal agreement with masculine controllers in the contemporary corpus.

As shown in Tables 17 and 18, agreement rates with antecedents of either gender are not significantly different across the two components of the contemporary corpus. With masculine antecedents (Table 17), the agreement rate is 99\% in the RnaG component and $97 \%$ in the other component (or 100\% vs. 96\%, respectively, not counting semantic agreement). With feminine

\footnotetext{
23 The agreement rate with prepositional pronouns is higher when semantic agreement is not counted (100\%) than when it is (98\%), on account of one semantically agreeing feminine pronoun which does not agree syntactically with its antecedent (a grammatically masculine noun with a female referent).
} 
antecedents (Table 18), agreement rate in the RnaG component is as high as $58 \%$, but goes down to $28 \%$ when semantic agreement is not taken into account. In the non-RnaG component, on the other hand, only five pronouns had feminine antecedents, all of which were inanimate, and only one pronoun was found to agree syntactically with its antecedent. The difference in agreement rate between the two components tests was found to be statistically not significant whether semantic agreement is counted or not.

\begin{tabular}{lccccc}
\hline & \multicolumn{2}{c}{ Overall } & & \multicolumn{2}{c}{ Excl. sem. agr. } \\
\cline { 2 - 3 } \cline { 5 - 5 } & RnaG & Others & & RnaG & Others \\
\hline Agreeing & 127 & 85 & & 70 & 75 \\
Total & 128 & 88 & & 70 & 78 \\
$\%$ & 99 & 97 & & 100 & 96 \\
\hline & $\mathrm{p}=0.3066$ & & $\mathrm{p}=0.2471$ \\
\hline
\end{tabular}

Table 17. Pronominal agreement with masculine controllers in the contemporary corpus, RnaG vs. others.

\begin{tabular}{lccccc}
\hline & \multicolumn{2}{c}{ Overall } & & \multicolumn{2}{c}{ Excl. sem. agr. } \\
\cline { 2 - 3 } \cline { 5 - 6 } & RnaG & Others & & RnaG & Others \\
\hline Agreeing & 18 & 1 & & 5 & 1 \\
Total & 31 & 5 & & 18 & 5 \\
$\%$ & 58 & 20 & & 28 & 20 \\
\hline \multicolumn{3}{c}{} & $\mathrm{p}=0.1672$ & \multicolumn{2}{c}{$\mathrm{p}=1$} \\
\hline
\end{tabular}

Table 18. Pronominal agreement with feminine controllers in the contemporary corpus, RnaG vs. others.

\subsubsection{Summary}

Unlike what we have observed with regard to NP-internal agreement, the likelihood of syntactic agreement with the pronoun does depend on the gender of the controller in both corpora, rather than just in the contemporary one. However, the two corpora differ in that syntactic agreement with feminine antecedents is still the preferred option in the older corpus (it is observed over $80 \%$ of the time), while it is only found about half of the time in the contemporary one; when only nonsemantic agreement is considered, syntactic agreement with feminine antecedents in the contemporary corpus is found in only about one quarter of all cases. Feminine pronouns with inanimate antecedents appear to be very rare in the contemporary corpus.

\subsection{Summary of the findings}

Figure 1 provides a graphic summary of the findings. The graph has two rows: overall agreement rates are shown on the top one, non-semantic agreement rates on the bottom one. As can be seen, the only difference between the two rows is observed in the case of pronominal agreement. A comparison between the two corpora can be made for each target type: the dark-grey bars represent older-corpus rates and the light-grey bars contemporary-corpus rates. The diachronic differences in agreement rate with masculine controllers (cf. the two bar plots on the left-hand side of Figure 1) are not statistically significant for any target type. Moreover, as can be seen, agreement rates with masculine controllers are all near 100\%.

As regards feminine controllers, on the other hand, diachronic differences in agreement rate are 
statistically significant for all target types: agreement rates in the older corpus are significantly higher than in the contemporary one with all target types. Synchronically, agreement rates with feminine controllers are higher with the article and lower with adjectives and pronouns. When semantic agreement is not counted, pronominal agreement shows the lowest agreement rates in both corpora. Moreover, pronouns are the only target type for which statistically significant betweengender differences in agreement rate show up in both corpora.

Masculine controllers
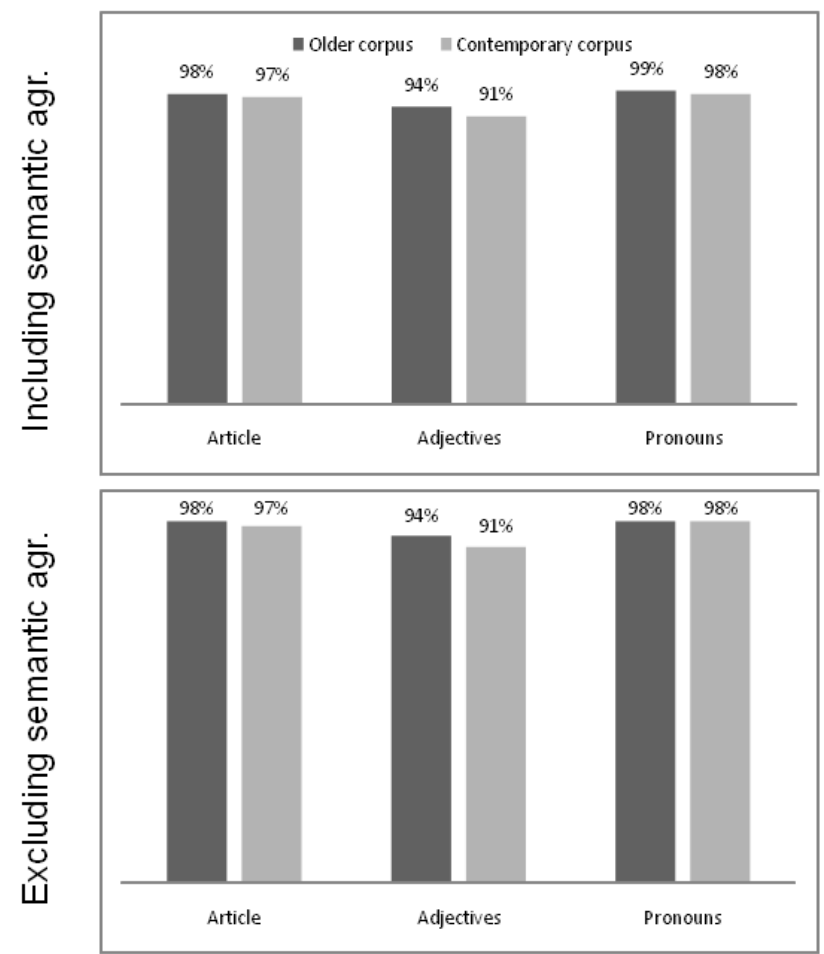

Feminine controllers
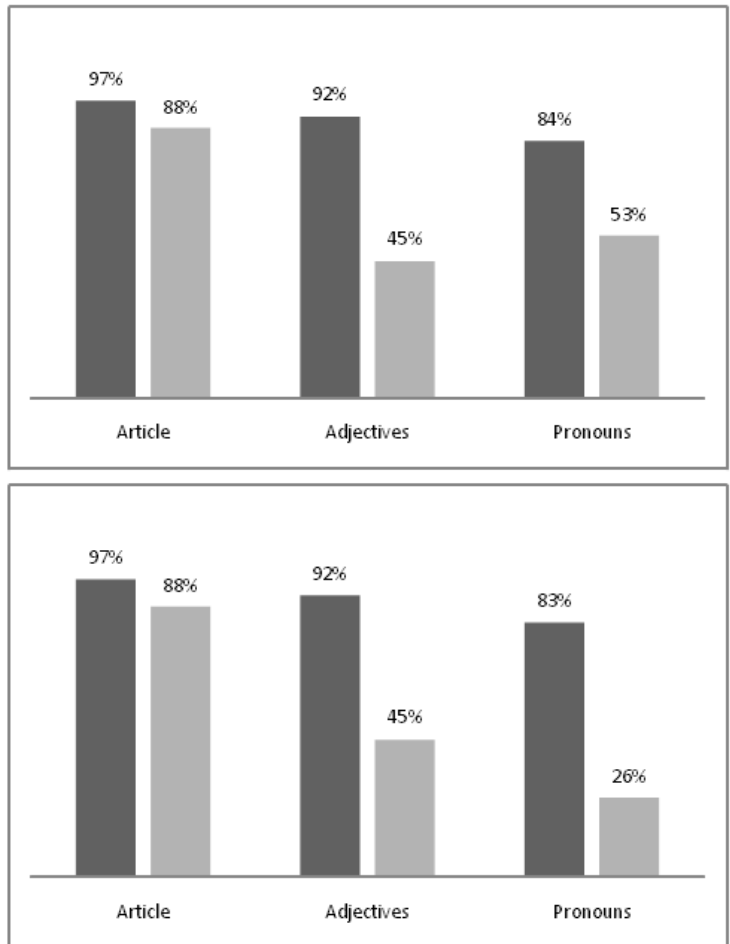

Figure 1. Agreement rates in Irish by corpus, gender and target type.

\section{Language-internal developments or contact-induced change?}

What clearly emerges from Figure 1 is a striking diachronic difference in agreement rates for feminine controllers, whereas the system appears to be stable insofar as masculine controllers are concerned. In the traditional system, agreement tends to be marked in a highly consistent way across the various target types; in the emerging one, feminine agreement forms tend to be increasingly rare within the noun phrase, except with the article, and almost completely absent for pronominal reference to inanimates. This suggests that the contemporary Irish situation might represent a stage along a development path leading to a new state of affairs, in which the emergent assignment system has ousted the older one completely. It is in this respect that a comparison with extinct or near-extinct cognates of Irish, as anticipated in §2, is particularly interesting.

Manx (Q-Celtic and thus genetically closer to Irish), which ceased to be spoken natively in the second half of the last century (Thomson 1992: 101-102), used to have the same gender-marking devices and assignment system as Irish (Kneen 1973: 49-50). Towards the end, however, agreement within the noun phrase had become extremely inconsistent, while pronominal agreement had already ceased to reflect the grammatical gender of inanimates (Thomson 1992: 118) and was 
instead always semantically determined (feminine for female animates, masculine for everything else; cf. Kneen 1973: 50, Broderick 1993: 239). In East Sutherland Gaelic (also Q-Celtic), which Nancy Dorian described as rapidly approaching extinction more than thirty years ago, the attributive adjective had ceased to productively mark gender agreement, while the use of masculine pronouns was the norm "even when mutation mark[ed] the noun as feminine within the NP" (Dorian 1976: 280). Finally, Cornish (P-Celtic) became extinct by the end of the eighteenth century (George 1993: 414): gender assignment and agreement marking in P-Celtic is not substantially different from that of Q-Celtic, but in Late Cornish gender assignment had become exclusively pronominal and semantic, based on the referent's sex (Jenner 1904: 78); all that survived of NP-internal agreement was a few fossilized remnants of initial consonant mutation in phrases headed by feminine singular nouns (Thomas 1992: 368).

As these languages died out, NP-internal agreement ceased to be productive and was lost (a), while pronominal agreement ceased to be syntactic and became almost exclusively semantic (b). In general, (b) seems to reach completion before (a): from this study of the Irish data it emerges that the occurrence of feminine pronouns with inanimate antecedents is extremely rare, while agreement within the NP is not completely dead and is in fact quite consistent at least with the article. Even in the extinct varieties we have surveyed, fossilized remnants of NP-internal agreement are sometimes observed, whereas pronominal agreement is exclusively semantic.

In view of the analogies between the end result of this process and the English gender system, notably the absence of NP-internal agreement and a semantic system of pronominal agreement, it might be argued that contact with English has played an important role in the observed changes, through a process of reinforcing of those linguistic structures shared by both contact varieties known as convergence (cf. Backus 2004, Bullock \& Toribio 2004). Before exploring this hypothesis further, the question might be asked whether a more economical explanation, not presupposing contact, might be plausible. Under this alternative hypothesis, formal gender assignment in Irish became less transparent due to a language-internal phonetic process and this in turn triggered its transformation.

The phonetic process in question is one of unstressed-syllable erosion. Word-final syllables, which typically carried the inflectional endings, were particularly affected by this phenomenon and had already been reduced or disappeared before the earliest available documents of any Insular Celtic language (i.e. both P-Celtic and Q-Celtic; cf. Lewis \& Pedersen 1974: 158f.). In Old Irish, the common ancestor of the Q-Celtic languages, the inflection system could survive thanks to the phonemicized distinction in consonant quality (palatal vs. non-palatal) and grammaticalized metaphonic processes caused by the quality of the lost syllable's vowel (see McCone 1994: 94). ${ }^{24}$ The subsequent vowel reduction to schwa that interested all unstressed proclitics in the 9th century

${ }^{24}$ An anonymous reviewer observes that the "formal correlates [of grammatical gender in Irish] are not always sufficient to keep the two genders apart" and that, therefore, the fact that it has survived for so long requires an explanation. This presumably refers to the fact that gender distinctions within the noun phrase cannot be made unless the noun, or the adjective, begins with a mutatable consonant or a vowel - except in the genitive, as seen in $\S 3$ above. However, this is not in any way peculiar to Irish. In modern Romance languages like French, Italian and Spanish, for instance, gender agreement is also neutralized if the noun begins with a vowel - in which case, the form of the singular article is the same for both genders as the final vowel is elided: cf. Italian l'ammontare 'the amount' (masculine) vs. l'appendice 'the appendix' (feminine); or when the attributive adjectives belongs to a morphological class that does not mark gender distinctions: cf. Spanish el hombre marroquí ‘the Moroccan man’ vs. la mujer marroquí 'the Moroccan woman'. Provided the input contains enough examples in which gender is distinguished, the language learners will acquire the gender system (see e.g. Lieven 2010 and, in this issue, De Vos \& De Vogelaer). To make the case that the Irish case is different from that of Italian or Spanish in this regard, it ought to be demonstrated that lexically conditioned agreement neutralization happens significantly more often in Irish than in other languages. 
is held responsible for the loss of the neuter gender, as the neuter article $a^{N}$ and masculine/feminine in became less distinguishable and the latter started to be used in lieu of the former (Thurneysen 1980: §245). However, the gender assignment system in its thus reduced form was able to survive. Its stability is confirmed, as we have seen, by the 1964 data. At the same time, as we have observed in $\S 3$ above, there has been some restructuring, which produced an increasingly phonological assignment system. This is related to the demise of case marking: the marking of the genitive, and where extant of the dative, is now rare in all dialects (cf. Hughes 1994: 628-635, Ó hUiginn 1994: 563-567, Ua Súilleabháin 1994: 492-493), while the accusative and nominative have long ceased to be distinguished (cf. Breatnach 1994: 241-243, McManus 1994: 363). Since number-marking morphology alone cannot keep the five declensions distinct in the absence of genitive marking (see Mac Eoin 1993: 114-115), the total collapse of the case system would make morphological gender assignment no longer possible. This would leave in place only a phonological correlation between consonant quality and gender.

Ultimately, the type of change we have been describing might well happen through languageinternal mechanisms in a contact-free situation. In French, for instance, the reduction and subsequent loss of the final syllables has resulted in a gender assignment system that is exceptionally complex when compared to other Romance languages (cf. Tucker et al 1977), and recent studies have focused on the uncertain and divergent assignment choices made by native speakers when faced with certain words (Ayoun 2009). ${ }^{25}$ In Dutch, for the same reasons, gender marking within the noun phrase has undergone a progressive decline, which is leading to a resemantisation of pronominal gender (Audring 2009; De Vos \& De Vogelaer, this issue); interestingly, speakers of southern dialects, where gender distinctions within the noun phrase are better preserved than in northern dialects, tend to reflect grammatical gender in pronominal agreement more than their northern counterparts (see De Vos \& De Vogelaer in this issue and references therein).

In the case of Irish, an internal-only explanation cannot answer the question why a system that had remained so conservative for so long after the loss of the final syllables has changed so dramatically over the last forty years or so, as reflected by the differences we have observed between the older and contemporary corpus.

Can contact with English explain this? The Census figures, as we have seen in §2 above, leave no doubt as to the dominance of English in Ireland. Especially in the second half of the 20th century, the wider availability of media like television and radio has contributed decisively to this state of affairs. The gradual and by now virtually total retreat of Irish before English in all domains of use obviously means a reduced exposure to the language in general and to its traditional forms in particular. Various attrition phenomena have been observed and reported on, whereby younger speakers tend to adopt structures which represent the "lowest common denominator" between Irish and English, reinforcing shared features and syntactic structures to the detriment of those that have no counterpart in English (Maguire 1991: 189f.). As we have seen, Maguire noted that the traditional opposition of palatality in the consonant system was largely ignored by the speakers she studied in the Belfast neo-Gaeltacht, ${ }^{26}$ who only retained it when it was phonemic in both Irish and

\footnotetext{
25 More uncertain is the case of English, whose gender system was also reduced to a semantically motivated, pronominally marked one. English was not ousted by a competing variety, but Curzan (2003: 43, 47-48) argues that the erosion of the final syllables which followed the "Germanic stress rule" cannot, by itself, explain the loss of grammatical gender in English, since other Germanic languages "underwent the same stress rule and some similar phonological changes” but did not lose grammatical gender (ibid.: 48); she concludes that "only external explanations involving language contact can account for the rapidity and the timing of the linguistic changes in late Old English and Early Middle English” (ibid.: 53).

26 As already mentioned, the parents of these young "non-traditional” native speakers were for the most part non-
} 
English. So, for instance, the /s/:/s'/ []] distinction - paralleled by the phonemic distinction between $/ \mathrm{s} /$ and $/ \int /$ in English - was retained, but the $/ \mathrm{r} /: / \mathrm{r}^{\prime} /$ distinction - which has no parallel in English - was not. Developments like these are particularly important, since, as we have already noted, the phonological opposition of palatality was key to the preservation of the declension system after the loss of the inflectional endings and would be among the few formal correlates of gender left to the language after the demise of case inflection.

As was also noted, in the final stages of Manx and Cornish - also ousted by English - gender agreement was largely a pronominal phenomenon motivated by semantic reference. It seems therefore that, although this type of change may be found in contact-less situations, the Irish case seems to be better explained by also factoring in language contact and convergence - which is in line with Nancy Dorian's observation that in situations of contact and obsolescence

[t]he types of change in formal language structure [...] are not notably different from those well established in the study of language change in general. But the timespan for change seems to be compressed [...] and the amount of change seems relatively large. (Dorian 1981: 154.)

There is of course a major difference between pronominal agreement in Irish and in English: the former has two genders while the latter has three, so that masculine pronouns in Irish fulfil the functions of both the neuter and masculine pronouns in English. This can be explained in terms of both markedness and convergence. Numerically, as we have seen, the masculine is the unmarked gender in Irish: masculine nouns are more frequent than feminine ones in both corpora, and masculine pronouns three to four times more frequent than feminine ones even in the older corpus, where more than half of the feminine pronouns refer to masculine antecedents. ${ }^{27}$ Structurally, the use of the masculine pronoun in Modern Irish parallels that of the neuter pronoun in English in complex anaphora, as discussed in $§ 5.3$ above, in cataphoric relation with declarative clauses, as in (11), and in impersonal expressions, as in (12).

$$
\begin{aligned}
& \text { Taithníonn } \underline{\text { sé }}{ }_{i} \quad \text { liom }[a \text { bheith anseo }]_{i} \\
& \text { please.PRs 3sG.M with.1sG PTC be.vN here } \\
& \text { 'I like to be here' (lit. 'it pleases me to be here'; from Ó Siadhail 1989: 274) } \\
& \text { Tá } \underline{\text { sé } a \text { trí a chlog }} \\
& \text { be.PRs 3sG.M PTC three o'clock } \\
& \text { 'It is three o’clock' (Ó Dochartaigh 1992: 39) }
\end{aligned}
$$

Therefore, the re-assignment of traditionally feminine inanimates to the masculine gender in pronominal agreement in Irish is both typologically to be expected and consistent with the convergence hypothesis, in that it represents a synthesis of what the two systems in contact already had in common or, to paraphrase Toribio (2004: 167), the most parsimonious assignment system that serves both languages.

\section{Final remarks}

To conclude, the limitations of this study should be pointed to. Given that certain target types seem to have become less frequent than in the older corpus, the size of the contemporary corpus has not allowed us to observe enough instances of certain agreement contexts to carry out meaningful statistical tests of significance for some of them. For example, when it was observed that there was no statistically significant difference in agreement rate between the two components of the

native speakers.

27 Also cf. Fowkes (1957). 
contemporary corpus for a certain target type or a certain gender, this might be due at least in part to the small counts involved in the comparison. Although it has been observed that "the Irish spoken in the English-speaking and Irish-speaking areas is rapidly converging" and "an urbanised koine is developing among Irish speakers of high competence, irrespective of background” (Ó Murchú 1988: 243), we cannot rule out that the analysis of a larger corpus of contemporary spoken Irish might show that major differences between the two varieties do in fact exist in the area of gender agreement.

Especially for one target type, attributive adjectives, further research ought to be conducted with larger samples. As we have seen, adjectives in Irish seem to be in a sort of limbo, as they have not ceased to mark gender agreement altogether but do so less consistently than the article: the study of a larger sample can therefore capture a picture of ongoing language change and help answer a number of interesting questions: what are the factors at play in the process? Is semantic agreement more resilient than non-semantic agreement? How important are factors such as collocation frequency and lexical frequency? Are certain initial consonants less likely to be lenited, thereby contributing to the spread of historically masculine agreement forms at the expenses of the feminine ones? These are questions that it would be interesting to answer, but a larger amount of data is necessary in order to do so.

\section{References}

Akutagawa, Michie. 1987. A linguistic minority under the protection of its own ethnic state: a case study in an Irish Gaeltacht. In G. Mac Eoin, A. Ahlqvist \& D. Ó hAodha, eds. Third International Conference on Minority Languages: Celtic papers. Clevedon: Multilingual Matters, 125-146.

Audring, Jenny. 2009. Reinventing pronoun gender. Netherlands Graduate School of Linguistics / Landelijke - LOT. URL: http://tiny.cc/4fc2x, accessed 24 February 2011.

Ayoun, Dalila. 2009. The (in)stability of grammatical gender assignment and agreement by French native speakers. Paper presented at AAAL 2009, Denver, Colorado.

Backus, Ad. 2004. Convergence as a mechanism of language change. Bilingualism: Language and Cognition 7: 179-181.

Breatnach, Liam. 1994. An Mhéan-Ghaeilge [Middle Irish]. In McCone et al., eds. 221-333.

Breatnach, R. A. 1964. The Irish revival reconsidered. Studies 53: 18-30.

Broderick, George. 1993. Manx. In M. J. Ball \& J. Fife, eds. The Celtic languages. London: Routledge, 228-285.

Bullock, Barbara E. \& Almeida Jacqueline Toribio. 2004. Introduction: convergence as an emergent property in bilingual speech. Bilingualism: Language and Cognition 7: 91-93.

Caighdeán. 1979[1958]. Gramadach na Gaeilge agus litriú na Gaeilge: An caighdeán oifigiúil [Grammar and spelling of the Irish language: The official standard]. Baile Átha Cliath: Oifig an tSoláthair.

Carnie, Andrew Hay. 1995. Non-Verbal Predication and Head-Movement. MIT, Ph.D. thesis.

Consten, Manfred, Mareile Knees \& Monika Schwarz-Friesel. 2007. The function of complex anaphors in texts: evidence from corpus studies and ontological considerations. In M.

Schwarz-Friesel, M. Consten \& M. Knees, eds. Anaphors in text: Cognitive, formal and applied approaches to anaphoric reference. Amsterdam and Philadelphia: John Benjamins, 81-102.

Corbett, Greville G. 1991. Gender. Cambridge: Cambridge University Press.

CSO. 2006. Census 2006, Volume 9: Irish language. Central Statistics Office Ireland. URL: http://tiny.cc/4npqe, last accessed 24 February 2011.

Curzan, Anne. 2003. Gender shifts in the history of English. Cambridge: Cambridge University 
Press.

de Bhaldraithe, Tomás. 1953. Gaeilge Chois Fhairrge: An deilbhíocht [The Irish of Cois Fhairrge: Morphology]. Baile Átha Cliath: Institiúid Árd-Léinn Bhaile Átha Cliath.

De Vos, Lien \& Gunther De Vogelaer (this issue). Dutch gender and the locus of morphological regularisation.

Doherty, Cathal. 1996. Clausal structure and the modern Irish copula. Natural Language \& Linguistic Theory 14: 1-46. URL: http://tiny.cc/cgw2y, accessed 24 February 2011.

Dorian, Nancy C. 1976. Gender in a terminal Gaelic dialect. Scottish Gaelic Studies 12: 279-282.

Dorian, Nancy C. 1981. Language death: The life cycle of a Scottish Gaelic dialect. Philadelphia: University of Pennsylvania Press.

Dorian, Nancy C. 1994. Purism vs. compromise in language revitalization and language revival. Language in Society 23: 479-494.

Fowkes, Robert A. 1957. Gender redistribution in Keltic: a preliminary study. In E. Pulgram, ed. Studies presented to Joshua Whatmough on his sixtieth birthday. 'S-Gravenhage: Mouton, 3946.

George, Ken. 1993. Cornish. In M. J. Ball \& J. Fife, eds. The Celtic languages. London: Routledge, 410-468.

George, Ken \& George Broderick. 1993. The revived languages: modern Cornish and modern Manx. In M. J. Ball \& J. Fife, eds. The Celtic languages. London: Routledge, 644-663.

Hickey, Raymond. 2003. Reanalysis and typological change. In R. Hickey, ed. Motives for language change. Cambridge: Cambridge University Press, 258-278.

Hughes, Art. 1994. Gaeilge Uladh [Ulster Irish]. In In McCone et al., eds. 611-660.

Jenner, Henry. 1904. A handbook of the Cornish language chiefly in its latest stages with some account of its history and literature. London: David Nutt.

Jones, Mari C. 1998. Language obsolescence and revitalization: Linguistic change in two sociolinguistically contrasting Welsh communities. Oxford: Clarendon Press.

Kneen, J. J. 1973. A grammar of the Manx language. Yn Cheshaght Ghailckagh (The Manx Gaelic Society).

Lewis, Henry \& Holger Pedersen. 1974[1961]. A concise comparative Celtic grammar. Göttingen: Vandenhoeck \& Ruprecht.

Lieven, Elena. 2010. Input and first language acquisition: evaluating the role of frequency. Lingua 120: 2546-2556.

Mac Eoin, Gearóid. 1993. Irish. In M. J. Ball \& J. Fife, eds. The Celtic languages. London: Routledge, 101-144.

Maguire, Gabrielle. 1991. Our own language: An Irish initiative. Clevedon: Multilingual Matters.

McCone, Kim. 1994. An tSean-Ghaeilge agus a réamhstair [Old Irish and its prehistory]. In McCone et al., eds. 61-219.

McCone, Kim, Damian McManus, Cathal Ó Háinle, Nicholas Williams \& Liam Breatnach, eds. 1994. Stair na Gaeilge [The history of Irish]. Maigh Nuad: Roinn na Sean-Ghaeilge, Coláiste Phádraig.

McManus, Damian. 1994. An Nua-Ghaeilge Chlasaiceach [Classic Modern Irish]. In McCone et al., eds. 335-445.

Nic Pháidín, Caoilfhionn. 2003. ‘Cén fáth nach?’ - Ó chanúint go criól [‘Why not?’ - From dialect to creole]. In R. Ní Mhianáin, ed. Idir lúibíní: Aistí ar an léitheoracht agus ar an litearthacht. Baile Átha Cliath: Cois Life, 113-130.

Ó Baoill, Dónall P. 1988. Language planning in Ireland: the standardization of Irish. In P. Ó Riagáin, ed. Language planning in Ireland (International Journal of the Sociology of Language 70). Berlin: Mouton de Gruyter, 109-126.

Ó Curnáin, Brian. 2007a. The Irish of Iorras Aithneach County Galway, Volume I. Dublin: Dublin Institute for Advanced Studies. 
Ó Curnáin, Brian. 2007b. The Irish of Iorras Aithneach County Galway, Volume II. Dublin: Dublin Institute for Advanced Studies.

Ó Dochartaigh, Cathair. 1992. The Irish language. In D. MacAulay, ed. The Celtic languages. Cambridge: Cambridge University Press, 11-99.

Ó Flatharta, Peadar. 1989. The teaching of Irish as a first language in primary schools in the Gaeltacht. Teanga 9: 75-83.

Ó Giollagáin, Conchúr \& Seosamh Mac Donnacha. 2008. The Gaeltacht today. In C. Nic Pháidín \& S. Ó Cearnaigh, eds. A new view of the Irish language. Dublin: Cois Life, 108-120.

Ó hUiginn, Ruairí. 1994. Gaeilge Chonnacht [Connacht Irish]. In McCone et al., eds. 539-609.

Ó Murchú, Máirtín. 1988. Diglossia and interlanguage contact in Ireland. Language, Culture and Curriculum 1: 243-249.

Ó Nualláin, Gearóid. 1911. Gadelica minora. The Irish Ecclesiastical Record 4th series, Volume XXX: 33-42, 137-144, 361-368, 501-508, 609-619.

Ó Sé, Diarmuid. 2000. Gaeilge Chorca Dhuibhne [The Irish of Corca Dhuibhne]. Baile Átha Cliath: Institiúid Teangeolaíochta Eireann.

Ó Siadhail, Mícheál. 1984. A note on gender and pronoun substitution in modern Irish dialects. Ériu 35: 173-177.

Ó Siadhail, Mícheál. 1989. Modern Irish: Grammatical structure and dialectal variation. Cambridge: Cambridge University Press.

Punch, Aidan. 2008. Census data on the Irish language. In C. Nic Pháidín \& S. Ó Cearnaigh, eds. A new view of the Irish language. Dublin: Cois Life, 43-54.

Thomas, Alan R. 1992. The Cornish language. In D. MacAulay, ed. The Celtic languages. Cambridge: Cambridge University Press, 346-369.

Thomson, Robert L. 1992. The Manx language. In D. MacAulay, ed. The Celtic languages. Cambridge: Cambridge University Press, 100-136.

Thurneysen, Rudolf. 1980. A grammar of Old Irish. Revised and enlarged edition with supplement. Dublin: Dublin Institute for Advanced Studies.

Toribio, Almeida Jacqueline. 2004. Convergence as an optimization strategy in bilingual speech: evidence from code switching. Bilingualism: Language and Cognition 7: 165-173.

Tucker, G. R. \& W. E. Lambert \& A. A. Rigault (1977). The French speaker's skill with grammatical gender: An example of rule-governed behavior. The Hague: Mouton.

Ua Súilleabháin, Seán. 1994. Gaeilge na Mumhan [Munster Irish]. In McCone et al., eds. 479-538.

Wigger, Arndt, ed. 2000. Caint Chonamara: Bailiúchán Hans Hartmann, Imleabhar IX: Ros Muc [The spoken language of Connemara: Hans Hartmann's collection, Vol. IX: Ros Muc]. Universität Bonn. 